\title{
Isoprene and monoterpene measurements in a secondary forest in northern Benin
}

\author{
J. E. Saxton ${ }^{1}$, A. C. Lewis ${ }^{1}$, J. H. Kettlewell ${ }^{1}$, M. Z. Ozel $^{2}$, F. Gogus ${ }^{3}$, Y. Boni ${ }^{4}$, S. O. U. Korogone ${ }^{5}$, and D. Serça ${ }^{6}$ \\ ${ }^{1}$ University of York, Department of Chemistry, Heslington, York, YO10 5DD, UK \\ ${ }^{2}$ The University of Pamukkale, Faculty of Science \& Arts, Chemistry Department, P.O. 286, 20017, Denizli, Turkey \\ ${ }^{3}$ The University of Gaziantep, Engineering Faculty, Food Engineering Department, 27310 Gaziantep, Turkey \\ ${ }^{4}$ Appui à la Gestion Concertée des Ressources Naturelles (AGesCo-RN), Parakou, Benin \\ ${ }^{5}$ Laboratoire d'Etude et de Recherche Forestière, Université de Parakou, Parakou, Benin \\ ${ }^{6}$ Laboratoire d'Aérologie, UMR 5560 CNRS, Université Paul Sabatier, Toulouse III, Toulouse, France
}

Received: 18 January 2007 - Published in Atmos. Chem. Phys. Discuss.: 11 April 2007

Revised: 19 July 2007 - Accepted: 30 July 2007 - Published: 6 August 2007

\begin{abstract}
The biogenic volatile organic compound (BVOC) composition of ambient air at a rural field site near Djougou, Benin has been studied as part of the AMMA (African Monsoon Multidisciplinary Analysis) project. Ambient air was sampled during day and night during the period 2 June 2006 to 13 June 2006. Gas samples from within the forest canopy and from branch and cuvette enclosure systems for four vegetation species were also obtained and emissions flux estimates made. All samples were analysed for the presence of isoprene, monoterpenes and sesquiterpenes by either gas chromatography-time of flight mass spectrometry (GC-TOF/MS) or comprehensive gas chromatography-time of flight mass spectrometry (GCxGC-TOF/MS). Concentrations of isoprene ranged from a few tens of pptV to in excess of $3000 \mathrm{pptV}$. Similar concentration ranges for certain monoterpenes were also observed. Limonene was seen at a maximum concentration in ambient air of $5000 \mathrm{pptV}$. The combination of leaf-level observations and direct analysis of dried vegetation samples suggests that emissions of terpene species from indigenous species are unlikely to account for the unexpectedly high ambient concentrations of monoterpenes. Leaf scale emission measurements and biological sample analysis indicated that Anacardium occidentale, a non-native crop species found throughout the tropics, was the dominant source of monoterpenes at this location. These preliminary findings suggest that activities involving species replacement have potential implications for the chemistry of the African troposphere that have not been widely considered previously.
\end{abstract}

Correspondence to: A. C. Lewis

(ac15@york.ac.uk)

\section{Introduction}

The emission of isoprene and other higher terpenoids, including monoterpenes and sesquiterpenes, from vegetation is well documented (Fuentes et al., 2000). Biogenic emissions account for a significant proportion of all volatile organic compounds (VOCs) emitted into the troposphere. Using models, it has been estimated that globally the principal natural sources of organic compounds are woods, crops and shrubs with a combined flux in the region of $1135 \mathrm{TgC}$ year $^{-1}$, with the majority of this flux attributed to isoprene (Guenther et al., 1995). In comparison, anthropogenic nonmethane VOC emissions are much lower with estimates of 110 to $150 \mathrm{Tg} \mathrm{year}^{-1}$ reported (Muller, 1992; Piccot et al., 1992).

The oxidation reactions of VOCs in the atmosphere have been described extensively; previous laboratory studies have demonstrated that biogenic volatile organic compounds (BVOCs) participate in reactions with ozone $\left(\mathrm{O}_{3}\right)$, the hydroxyl radical $(\mathrm{OH})$ and the nitrate radical $\left(\mathrm{NO}_{3}\right)$ to form a complex range of products including less volatile oxygenated species (Atkinson and Arey, 2003). Concurrently, field measurements have confirmed that BVOCs in the troposphere are implicated in the formation of secondary organic aerosol (Andreae and Crutzen, 1997; Kavouras et al., 1998; Yu et al., 1999; Kavouras et al., 1999) and in the generation of secondary gas phase species including ozone and $\mathrm{HCHO}$ (Trainer et al., 1987; Williams et al., 1997) through their oxidation reactions, resulting in an impact on air quality at the local and regional scale. In addition, the influence on the oxidative capacity of the atmosphere has the potential to have a global impact.

The strong links between vegetation emission fluxes and sunlight and/or temperature have seen tropical regions come under increasing scrutiny in an effort to understand the role

Published by Copernicus Publications on behalf of the European Geosciences Union. 


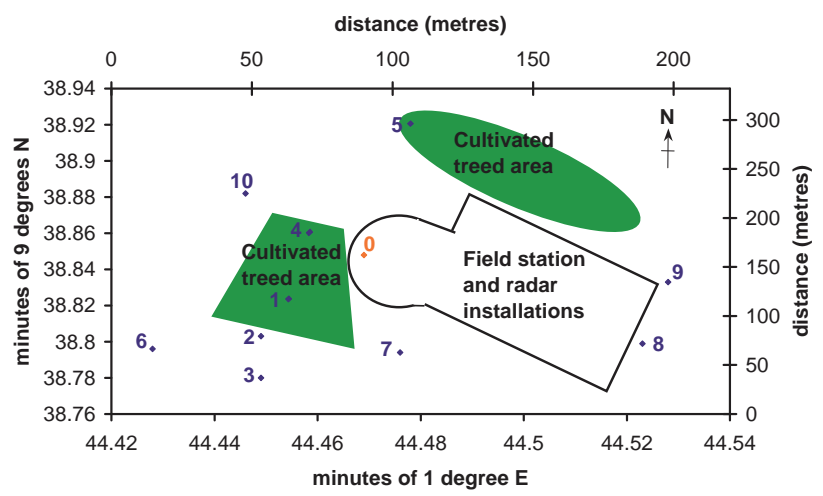

Fig. 1. Schematic illustration of survey stations at Nangantchori. The sampling tower (0) and survey stations are indicated.

of BVOC emissions in global tropospheric chemistry and climate, with the Amazon particularly subject to intensive study in recent years (Kesselmeier et al., 2000). The abundance of species found in tropical ecosystems makes the task of defining emissions from vegetation particularly challenging. Most current global BVOC emission inventories are based on model results (Guenther et al., 1995; Guenther et al., 2006) and both qualitative and quantitative data for many regions, including the African regions, are limited. In addition, many BVOC compounds are highly reactive short-lived species and their detection and identification in itself is far from trivial.

Previous work in Africa, including the SAFARI and EXPRESSO campaigns (Lindesay et al., 1996; Delmas et al., 1999; Swap et al., 2002, 2003), has focussed on southern and central Africa respectively, and particularly on biomass burning which is most common during the dry season. The data on biogenic emissions of vegetation in tropical Africa during the EXPRESSO campaign included ambient air measurements from aircraft and ground-based platforms during the biomass burning season in 1996 (Greenberg et al., 1999), an extensive survey of central African plants and inventory of their isoprene emissions with tentative assessment of other stored VOCs (Klinger et al., 1998), and tower measurements of fluxes carried out at the beginning and end of the wet season in 1996 (Serca et al., 2001). The tower measurements, carried out in a tropical mixed forest, showed that isoprene emission was largely confined to a small number of species, and emissions of monoterpenes were much less significant than isoprene. This was similar to results reported from the Amazon at a remote tropical forest site suggesting that isoprene was the dominant emitted species (Kesselmeier et al., 2000; Kuhn et al., 2002).

The vegetation zones in West Africa range from arid semidesert to moist coastal zones, each with their own predominant species and conditions. Aerosol composition measurements have been reported for carbonaceous aerosol, which included the seasonably variable sources from biomass burn- ing and biogenic emissions, in the Ivory Coast by Cachier et al. (1985), and by Lacaux et al. (1991) during the DECAFE campaign, however gas phase biogenic emissions, particularly in rural areas of West Africa, generally remain poorly defined. The EXPRESSO survey of central Africa identified some species, with a high isoprene emission potential, which are also found in western Africa, but it is known that emissions from vegetation are both species dependent and dependent on the local environmental conditions (Kuhn et al., 2002), and therefore both quantification of isoprene emissions, and the extent of monoterpene and higher terpenoid compound emissions are largely unverified for West Africa. Clearly, it is necessary to assess biogenic emissions in the region further to obtain a more comprehensive picture for tropical Africa.

To complement both the available measurement data and estimates from models, measurements of BVOCs in ambient air and the canopy, and emissions from vegetation were carried out at a field station in northern Benin, a region characterised by woodlands and savannas, during one of the intensive phases (monsoon onset period 2 June 2006 to 13 June 2006) of the African Monsoon Multidisciplinary Analysis (AMMA) project. Samples of leaves from selected grass and tree species were also collected for direct analysis of biological volatile content and in particular for the presence of terpenoid compounds. The results presented here provide some insight into the diurnal, temperature and speciesspecific emissions of isoprene and monoterpenes for plant species commonly found in this vegetation zone.

\section{Experimental}

\subsection{Site description}

Measurements were carried out in northern Benin at Nangantchori $\left(09^{\circ} 38.84 \mathrm{~N}, 001^{\circ} 44.46 \mathrm{E}\right)$, located $10 \mathrm{~km}$ east of Djougou, at one of the sites forming the AMMA Oueme mesoscale site. The site was located in a clearing surrounded by secondary woodland, cultivated crops and fallow that had been subjected to some small-scale vegetation burning within the preceding five years. The nearest road was the Djougou to Parakou road and was located less than $0.5 \mathrm{~km}$ from the site. This site lies within a Southern Sudanian vegetation-type zone characterised by woodland savannah comprising Isoberlinia species ${ }^{1}$. A summary of the most prevalent species found at this site, with an estimate of the density, is shown in Table 1. A schematic showing the general layout of the site and the location of the survey plots is shown in Fig. 1.

\footnotetext{
${ }^{1}$ Atlas of natural and agronomic resources of Niger and Benin, http://www.uni-hohenheim.de/ atlas308/a_overview/a3_1/ html/english/nframe.htm
} 
Table 1. Incidence of the most prevalent species at Nangantchori field site.

\begin{tabular}{|c|c|c|}
\hline Vegetation type & Species & Stations at which present ${ }^{4}$ \\
\hline \multirow[t]{19}{*}{ Trees and shrubs } & Anacardium occidentale & $1(10 \%), 4(30 \%), 5(30 \%), 9(20 \%), 10$ \\
\hline & Burkea africana & $1,2(3 \%), 3,5,6,7(2 \%)$ \\
\hline & Daniellia oliveri & $\begin{array}{l}1(30 \%), 2(15 \%), 3(10 \%), 4(40 \%), 5(25 \%), 6, \\
7(3 \%), 8(25 \%), 9(5 \%), 10(15 \%)\end{array}$ \\
\hline & Isoberlinia doka & $1(4 \%), 2(40 \%), 3(30 \%), 6(45 \%), 7(60 \%)$ \\
\hline & Parkia biglobosa & $5,7,8(5 \%), 9(20 \%)$ \\
\hline & Vitellaria paradoxa & $1(30 \%), 2,4,5,6,7,8(15 \%), 9(15 \%), 10(30 \%)$ \\
\hline & Annona senegalensis & $1,3,4(10 \%), 5,6,7,8(5 \%), 9$ \\
\hline & Byrsocarpus coccineus & $6,8(2 \%), 9$ \\
\hline & Cochlospermum planchonii & $1(2 \%)$ \\
\hline & Entada africana & $1(2 \%), 2(10 \%), 3,6(5 \%), 7,9$ \\
\hline & Fluggea virosa & $1,5(5 \%), 8(20 \%), 9$ \\
\hline & Lanea acida & $1,2(3 \%), 3,6(2 \%), 7$ \\
\hline & Monotes kerstingii & $3(5 \%), 6(5 \%), 7(7 \%)$ \\
\hline & Opilia amentacea & $2,3,6(32 \%), 7(10 \%), 8$ \\
\hline & Parinari curatellifolia & $2,3,6(5 \%), 8$ \\
\hline & Piliostigma thoningii & $10(4 \%)$ \\
\hline & Stereospermum kunthianum & $6(2 \%), 10$ \\
\hline & Tectona grandis & $9(10 \%)$ \\
\hline & Uapaca togoensis & $1,3,6(12 \%), 7$ \\
\hline \multirow[t]{17}{*}{ Herbaceous plants } & Andropogon gayanus & $1(15 \%), 4,5(5 \%), 6(5 \%), 7(5 \%), 8(10 \%)$ \\
\hline & Dactylotenium aegyptium & $10(30 \%)$ \\
\hline & Andropogon chinensis & $2,3(10 \%), 6(5 \%), 7(5 \%)$ \\
\hline & Andropogon schirensis & $2(20 \%), 3(20 \%), 6(20 \%), 7(10 \%)$ \\
\hline & Brachiaria falcifera & $1(3 \%), 2,3,5,8(10 \%), 9(10 \%), 10$ \\
\hline & Brachiaria serrata & $3,6(5 \%), 7(5 \%)$ \\
\hline & Brachiaria villosa & $4(10 \%)$ \\
\hline & Hyperthelia dissoluta & $1,4,5(30 \%), 10$ \\
\hline & Hyparrhenia involucrata & $1(20 \%)$ \\
\hline & Hyparrhenia smithiana & $2(5 \%), 3(25 \%), 6,7(25 \%)$ \\
\hline & Imperata cylindrica & $1,4(5 \%), 5(5 \%), 8(5 \%)$ \\
\hline & Monocymbium ceresiiforme & $6(5 \%)$ \\
\hline & Schizachyrium sanguineum & $3,6(5 \%), 7(5 \%)$ \\
\hline & Setaria pumila & $8,10(3 \%)$ \\
\hline & Sporobolus pyramidalis & $1(1 \%), 8$ \\
\hline & Tridax procumbens & $4,10(20 \%)$ \\
\hline & Urelytrum muricatum & $7(4 \%)$ \\
\hline
\end{tabular}

${ }^{4}$ For species that are dominant at a particular station, an estimate of ground cover is shown in parentheses beside the station identification number. Station identification numbers correspond to the locations shown in Fig. 1.

\subsection{Sample collection}

Gas samples were collected onto stainless steel thermal desorption tubes filled with Carbopack B, Carbopack C and Carbosieve SIII (Supelco, Bellefonte, PA, USA). During storage and transportation, before and after sampling, tubes were sealed with brass Swagelok fittings with nylon ferrules. Tubes were stored at ambient temperature off-site and transported back to the UK for analysis by GC-TOF/MS or GCxGC-TOF/MS. Toluene $\mathrm{D}_{8}$ internal standard $(30 \mathrm{~mL}$, $52 \mathrm{ppb}$ ) supplied by Spectra Gases (Alpha, NJ, USA) was added to samples and blank tubes prior to processing. Each tube was desorbed at 220 to $250^{\circ} \mathrm{C}$ under a helium flow (BOC gases, Guildford, UK) for four minutes onto an identical clean adsorbent tube. A condenser in an ice-water bath was placed between the two tubes to trap out water collected on the sample tubes. The efficiency of analyte transfer was 83 to $96 \%$, with the caveat that these values represent dry gas standard samples because evaluation of wet samples was not possible. 


\subsubsection{Ambient air samples}

An air inlet was suspended at a height of either $2.5 \mathrm{~m}$ or $5 \mathrm{~m}$ above ground in a compound surrounded by vegetation. A quartz fibre filter (Whatman International, Maidstone, UK) was placed on the inlet to prevent particulate material entering the sampling line. The filter was changed periodically. Air was drawn through Teflon tubing (1/8" o.d.) to the pump and sampling unit housed indoors a distance of less than $15 \mathrm{~m}$ from the location of the suspended inlet. A cold finger (glass and stainless steel condenser held in an ice bath) was employed to reduce the humidity of the air passing through a potassium iodide (KI) trap and into the sample tubes. The KI ozone scrubber consisted of 100 to $200 \mathrm{mg}$ solid material held in a short length of Teflon tubing using silanised glass wool. The KI trap was changed twice a day. No significant loss of monoterpene species was observed during method development when this arrangement was used. The tubes were housed in a sampling unit containing a mass flow controller (MKS Instruments Ltd, Altrincham, UK), 16 position stream selecting valve (valvco VIVI, Switzerland) and a thermostatically controlled block held at 20 to $30^{\circ} \mathrm{C}$. Sample flow rates, pressures and temperature for each sample were recorded using an internal Campbell data logger. Samples $(1.5$ to $3 \mathrm{~L}$ depending on experiment) were collected at flow rates over the range 30 to $75 \mathrm{~mL} \mathrm{~min}^{-1}$.

\subsubsection{Canopy samples}

A sample tube inlet was suspended over a tree branch typically 8 to $10 \mathrm{~m}$ above ground level. Air was drawn through Teflon tubing (1/4" o.d.) at a flow rate of $100 \mathrm{ml} \mathrm{min}^{-1}$, set using a needle valve assembly. An ozone scrubber was placed in-line before the sample tube. Each sample was collected for $20 \mathrm{~min}$.

\subsubsection{Branch and leaf enclosure measurements}

Branch enclosure measurements were carried out using a $100 \mathrm{~L}$ Tedlar bag (SKC Limited, Dorset, UK). Small branches were selected to minimise contact between the vegetation and the walls of the bag. The bag was inflated with ambient air at a rate of approximately $3 \mathrm{~L} \mathrm{~min}^{-1}$ that was pumped through a hydrocarbon trap to remove hydrocarbons in the in-flowing air. Sampling was carried out after a period of one hour to allow stabilisation of the system. Air was drawn out of the bag onto adsorbent tubes at a flow rate of $100 \mathrm{~mL} \mathrm{~min}^{-1}$ using a second pump. Samples were collected for $30 \mathrm{~min}$. The temperature inside and outside the bag was monitored simultaneously. The temperature difference between the inside and outside of the bag was always less than $2^{\circ} \mathrm{C}$. The number of leaves on sampled branches was counted and representative leaves taken from each branch after sampling for drying and weighing.
A leaf cuvette constructed from Perspex using Neoprene to create a seal for the leaf chamber was used to determine leaf level emissions. The leaf cuvette was suspended from neighbouring branches to reduce stress on the sampled area. Sampling was carried out on selected leaves exposed to shade or full sunlight and that showed no visible signs of leaf injury. Ambient air was pumped into the cuvette through a hydrocarbon trap at a rate of $100 \mathrm{~mL} \mathrm{~min}^{-1}$. An equilibration period of 15 to $30 \mathrm{~min}$ was allowed to elapse before sampling took place. The collected outflow from the cuvette was $50 \mathrm{~mL} \mathrm{~min}^{-1}$ (the remaining gas flow vented outwards from the cuvette) and samples were collected onto tubes for 20 to $30 \mathrm{~min}$. The temperature inside the cuvette was monitored throughout sampling and was elevated compared to ambient temperature. A maximum difference of $13^{\circ} \mathrm{C}$ between inside and outside the cuvette was measured during sampling.

\subsection{Chromatographic analysis}

\subsubsection{Adsorption tube analysis}

Sample tubes were desorbed using an ATD 400 unit (PerkinElmer, Norwalk, CT, USA). Each tube was desorbed under a helium flow of approximately $60 \mathrm{~mL} \mathrm{~min}^{-1}$ at $350^{\circ} \mathrm{C}$ for $5 \mathrm{~min}$. Volatile compounds were cryofocused on a dual graphitized carbon black and carbon molecular sieve trap (Perkin Elmer) at $-30^{\circ} \mathrm{C}$, which after primary tube desorption was rapidly heated at a rate of $40^{\circ} \mathrm{C} \mathrm{s}^{-1}$ to $325^{\circ} \mathrm{C}$ and held for $30 \mathrm{~min}$. The desorbed volatiles were transferred to the GC column through a heated deactivated fused-silica line at $215^{\circ} \mathrm{C}$.

Quantification was achieved using clean adsorption tubes to which toluene $\mathrm{D}_{8}$ and a gas standard containing isoprene, $\alpha$-pinene, $\beta$-pinene and limonene (CK Gas Products Limited, Hook, Hampshire, UK) were added. Chromatographic retention and quantification of limonene in the gas standard was confirmed using individual standards of $\alpha$-pinene, camphene, $\beta$-pinene and limonene prepared in methanol solutions and injected onto clean adsorption tubes under a flow of helium $\left(100 \mathrm{~mL} \mathrm{~min}^{-1}\right)$. Standards were run for every 20 to 30 sample tubes analysed. Peak areas were corrected for instrument and handling backgrounds. Instrument backgrounds for isoprene and terpene compounds were assessed using clean tubes run after each set of standards and interspersed between sample tubes. Unsampled tubes were kept as field blanks to measure contamination during handling. Backgrounds ranged from less than 5 to $15 \mathrm{pptV}$ for the instrument to a maximum of 20 to $110 \mathrm{pptV}$ for an uncapped handling blank. Based on measurements of the gas standards, the precision was estimated to be 22 to $34 \%$ (CV) and accuracy $5 \%$. 


\subsubsection{Direct thermal desorption measurements}

The volatile organic content of biological samples was assessed using direct thermal desorption (DTD) and chromatographic analysis coupled to mass spectrometry. DTD was carried out using either an ATD 400 unit (Perkin-Elmer) for GC-MS or directly in a quartz inlet liner for GCxGCMS. This methodology follows that developed by Ozel et al. $(2007)^{2}$ for the characterisation of essential oil content within biological matrices. Although little used in atmospheric analysis, a broad correlation might be expected to exist in terms of speciation between high emissions and the presence of monoterpenes within the biological matrix. We exploit this method here as a means of probing potentially more reactive species that may be lost on atmospheric or enclosure sampling.

Using the ATD, dry biological samples ( 2 to $5 \mathrm{mg}$ ) were introduced into a stainless steel tube (desorption cartridge, $89 \mathrm{~mm} \times 4.5 \mathrm{~mm}$ I.D. $\times 6.5 \mathrm{~mm}$ O.D.), and heated under a helium flow at $150^{\circ} \mathrm{C}$ for $5 \mathrm{~min}$. This temperature is selected as one which is a compromise between efficient extraction and the minimisation of browning reactions (Ozel et al, 2006). Thermally extracted volatile compounds were cryofocused using a dual graphitized carbon black and carbon molecular sieve trap (Perkin Elmer) at $-30^{\circ} \mathrm{C}$, which after the primary desorption was rapidly heated at a rate of $40^{\circ} \mathrm{C} \mathrm{s}^{-1}$ to $325^{\circ} \mathrm{C}$ and held for $30 \mathrm{~min}$. The desorbed volatiles were transferred to the GC column through a heated fused-silica line at $215^{\circ} \mathrm{C}$.

\subsubsection{GC}

The GC-TOF/MS system consisted of an HP 6890 (Agilent Technologies, Palo Alto, CA, USA) gas chromatograph and a Pegasus III TOF-MS (LECO, St. Joseph, MI, USA). The column was a non-polar methyl polysiloxane DB5 type ( $60 \mathrm{~m} \times 0.25 \mathrm{~mm}$ i.d. $\times 1 \mu \mathrm{m}$ film thickness) from J\&W Scientific (Folsom, CA, USA). Helium (99.9999\% BOC gases) was used as a carrier gas. The initial temperature of the column was $35^{\circ} \mathrm{C}$ for $7 \mathrm{~min}$ and the subsequent temperature programme was a heating rate of $15^{\circ} \mathrm{C} \mathrm{min}{ }^{-1}$ until $240^{\circ} \mathrm{C}$ was reached and held for $10 \mathrm{~min}$. Detection was via TOF/MS with $70 \mathrm{eV}$ electron impact ionisation. The mass spectrometer used a push plate frequency of $5 \mathrm{kHz}$, with transient spectra averaging to give unit resolved mass spectra between 35 and $350 \mathrm{amu}$ at a rate of 50 spectra s$^{-1}$. Mass spectra were compared against the NIST ' 98 (National Institute of Standards and Technology, Gaithersburg, MD) mass spectral library. Compound identification was also informed by the use of authentic standards and the use of published Kovat's retention indices.

\footnotetext{
${ }^{2}$ Ozel, M. Z., Gogus, F., and Lewis, A. C.: Composition of Eucalyptus camaldulensis volatiles using direct thermal desorption coupled with comprehensive two-dimensional gaschromatography-time-of-flight mass spectrometry, J. Chromatographic Sci., submitted, 2007.
}

\subsubsection{Comprehensive GC}

The GCxGC-TOF/MS system consisted of an HP 6890 (Agilent Technologies) gas chromatograph and a Pegasus III TOF-MS (LECO). The first column was a non-polar HP5 $(30 \mathrm{~m} \times 0.32 \mathrm{~mm}$ i.d. $\times 0.25 \mu \mathrm{m}$ film thickness, Agilent Technologies) and the second column was a BP50 (SGE, Ringwood, Australia) housed in a secondary oven within the GC oven. A liquid nitrogen cooled gas jet midpoint modulator was used to enable two-dimensional separations. Helium (BOC gases) was used as a carrier gas. The initial temperature of the first column was $40^{\circ} \mathrm{C}$ for $0.5 \mathrm{~min}$ and the subsequent temperature programme was a heating rate of $5^{\circ} \mathrm{C} \mathrm{min}{ }^{-1}$ until $200^{\circ} \mathrm{C}$ was reached and held for $10 \mathrm{~min}$. The initial temperature of the second column was $55^{\circ} \mathrm{C}$ for $0.5 \mathrm{~min}$ and the subsequent temperature programme was a heating rate of $5^{\circ} \mathrm{C} \mathrm{min}^{-1}$ until $215^{\circ} \mathrm{C}$ was reached and held for $10 \mathrm{~min}$. Peak identification was made using TOF/MS with electron impact ionisation. The mass spectrometer used a push plate frequency of $5 \mathrm{kHz}$, with transient spectra averaging to give unit resolved mass spectra between 35 and $300 \mathrm{amu}$ at a rate of 50 spectra s$^{-1}$. Mass spectra were compared against the NIST '98 (National Institute of Standards and Technology, Gaithersburg, MD) mass spectral library.

\section{Results and discussion}

\subsection{BVOC ambient concentrations}

\subsubsection{Isoprene}

Isoprene was observed in ambient air samples taken at the site throughout the measurement period. Mean concentrations ranged from a few tens to hundred of $p p t V$ during darkness in the early hours of the morning, to in excess of $1000 \mathrm{pptV}$ during daylight hours, peaking during the middle of the day and being sustained through the afternoon. After sunset, concentrations generally reduced to less than $500 \mathrm{pptV}$ (Fig. 2). The range of concentrations measured varied widely; minimum detected concentrations were a few tens of pptV (limit of detection $5 \mathrm{pptV}$ ) and a maximum ambient air concentration of over $3000 \mathrm{pptV}$, sampled close to noon, was observed. These values are similar in magnitude to the isoprene concentrations $730-1820 \mathrm{pptV}$ reported by Serça et al. (2001) for the tropical forest of Northern Congo. Recently published data for isoprene emissions indicate that those originating in West Africa in the summer months (wet season) are less than half of the levels predicted for the Amazon (Guenther et al., 2006), and therefore comparatively, a lower impact on the oxidative capacity of the troposphere is expected. Isoprene emission from vegetation is currently considered to be dependent on photosynthetic processes and hence light. A diurnal cycle of ambient isoprene concentrations was clearly observed during this campaign (Fig. 2a) but significant levels of isoprene were observed during hours 


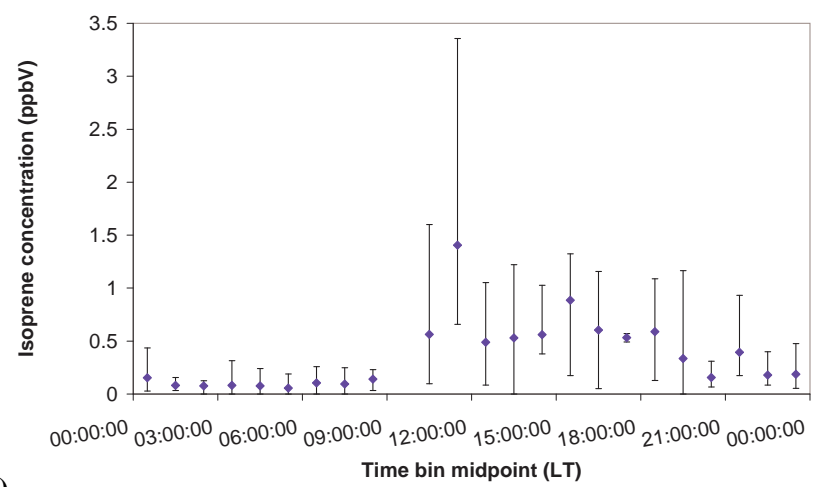

(a)

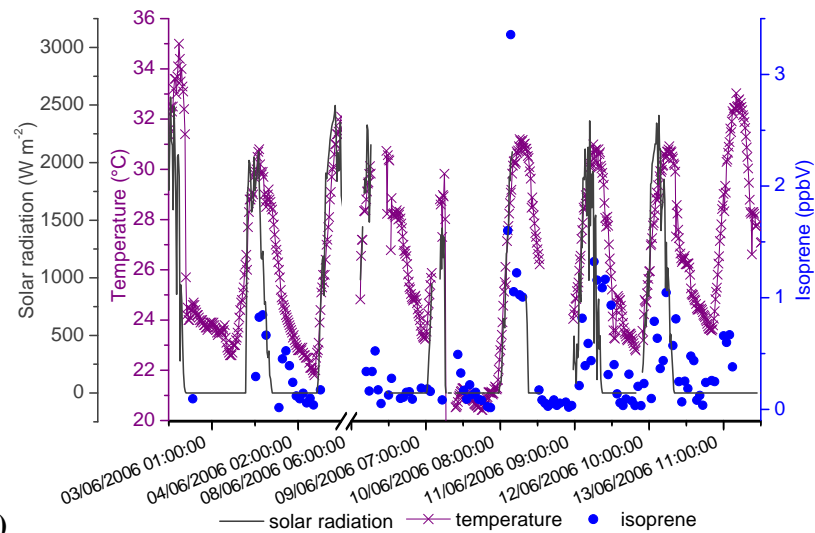

Fig. 2. (a) Mean, maximum and minimum concentrations of isoprene measured in ambient air between 7 and 13 June 2006 at Nangantchori, near Djougou, Benin. (b) Variation in diurnal isoprene concentrations sampled over 30 min (samples from 13 June 2006 only) or one hour periods with light intensity and temperature.

of darkness. Although isoprene emissions are generally expected to be close to zero soon after sunset (Guenther et al., 1991), the levels of OH radical also decrease at night and thus the isoprene lifetime in air is increased from an hour to over five hours if levels of nitrate radicals remain low (assuming an $\mathrm{OH}$ daytime concentration of $2 \times 10^{6}$ molecules $\mathrm{cm}^{-3}$ ). The observed levels of isoprene during the early part of the night were therefore considered consistent with the expected pattern for isoprene ambient air concentrations in a humid rural environment.

Emissions are also known to be sensitive to ambient temperature, a factor that has been incorporated into many emissions models in addition to light. A correlation between isoprene concentration and ambient air temperature was observed (Fig. 2b). The highest ambient concentrations of isoprene were only recorded when the ambient temperature was above $25^{\circ} \mathrm{C}$ which is consistent with the predictions of the model developed by Guenther et al. (1993). Several explanations for temperature sensitivity have been proposed, particularly with respect to plant protection benefits (Sharkey and Yeh, 2001; Penuelas et al., 2005) but further discussion of these is beyond the scope of this work.

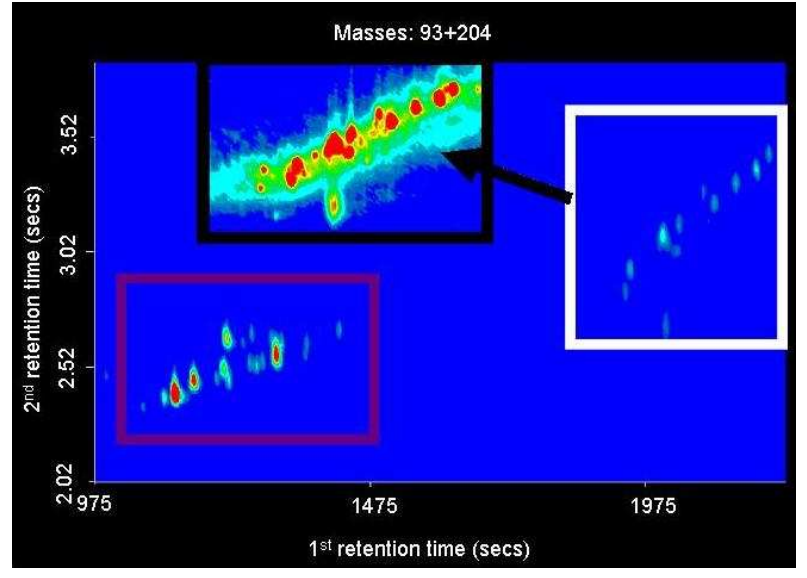

(a)

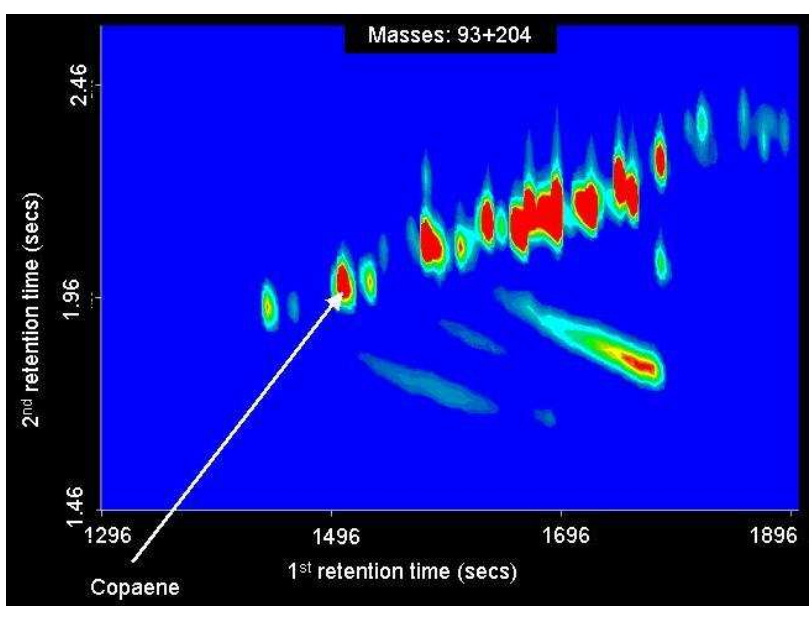

Fig. 3. (a) GCxGC chromatogram of ambient air sample taken at Nangantchori on 13 June 2006 between 13:12 and 13:42 (local time) showing monoterpenes (purple box) and sesquiterpenes (white box). The inset indicted with an arrow shows the sesquiterpene region at higher contrast for clarity. (b) GCxGC chromatogram of the Anacardium occidentale measured using direct thermal desorption. The sesquiterpene region of the chromatogram is shown for comparison with the ambient air sample.

The sample inlet on the tower was located approximately 5 to $50 \mathrm{~m}$ from the densest areas of vegetation surrounding the compound. Sampling was also carried out within the canopy itself at a distance of approximately $100 \mathrm{~m}$ from the tower. The isoprene levels within the native species canopy were comparable with ambient air measurements made at the tower. Concentrations ranged from a few tens of $\mathrm{pptV}$ to a maximum of over $500 \mathrm{pptV}$ around noon. These slightly lower concentrations can be attributed to the disproportionate influence from the species in which the inlet was suspended. Wind speeds were generally very low causing still conditions and a reduction in mixing of air pockets between the densely covered and more open areas around the site, therefore it is possible that if the plant in which the inlet was suspended 


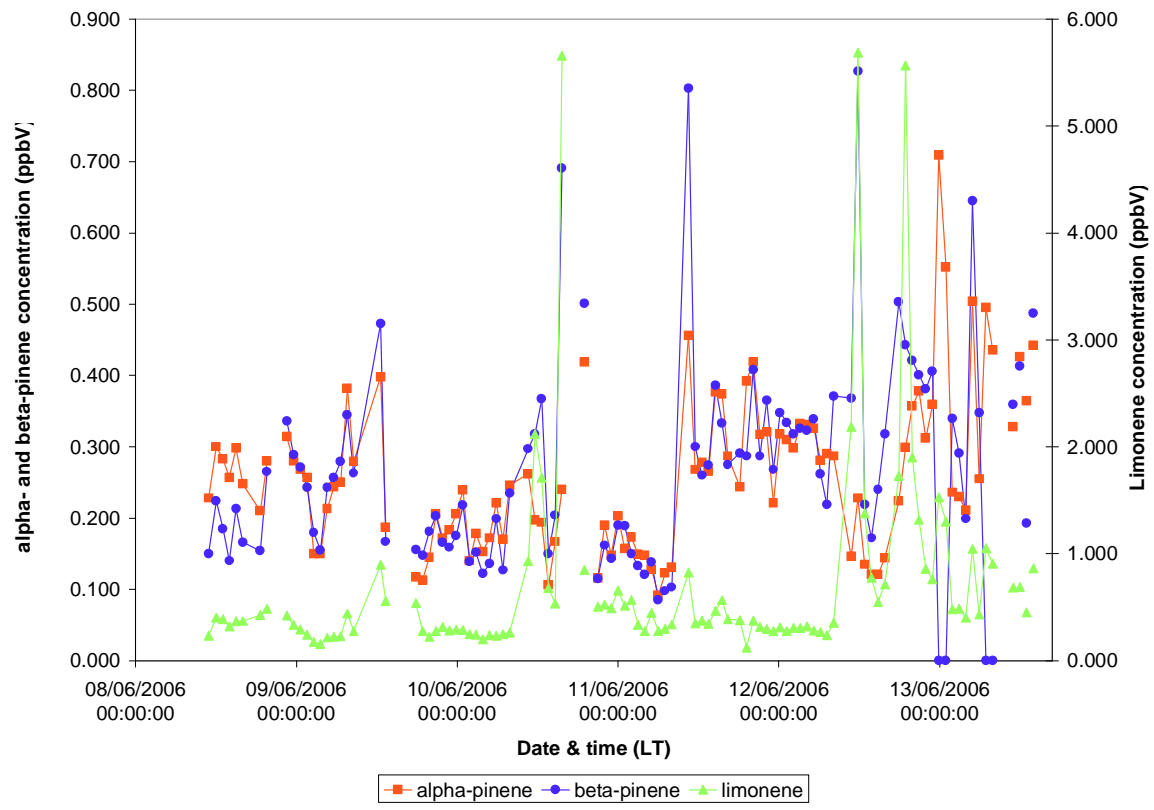

Fig. 4. Concentrations of $\alpha$-pinene, $\beta$-pinene and limonene in ambient air at Nangantchori, near Djougou, Benin during diurnal sampling in the period 8-13 June 2006. The samples were taken over 30 min (13 June 2006 only) or one hour periods and the points represent the mid-point of each sample period.

was not a high isoprene emitter, apparently low levels would occur in this very local environment. Klinger et al. (1998) found in central Africa that many species are not isoprene emitters and that isoprene emission is not consistent across all members of a species.

\subsubsection{Monoterpenes}

Several monoterpenes including $\alpha$-pinene, camphene, $\beta$ pinene, $\mathrm{p}$-cymene and limonene were detected in ambient air at this site. In addition, a number of unidentified species including monoterpene and sesquiterpene type structured compounds (Fig. 3) were found in the ambient air samples collected. Definitive identification of the specific compounds detected was limited by the lack of authentic standards and low confidence in library matching due to structural similarities within this class of compounds. Figure 4 shows ambient concentrations of $\alpha$-pinene, $\beta$-pinene, and limonene during day and night from samples taken during the period 7 to 13 June 2006. The general background level was of the order of a few hundred ppt $\mathrm{V}$ for each monoterpene species and there is a general diurnal variation for limonene and $\beta$-pinene.

GCxGC analysis air samples collected over shorter periods (30 min) also showed traces of several compounds whose chromatographic retention, estimated from Kovat's retention indices, and mass spectrum library identification were consistent with oxygenated terpenoid compounds such as camphor and menthol. Little further evidence of these oxygenated species was seen in other ambient air samples. The amounts of the compounds detected were small and conclu- sive identification of these analytes was not attained. Oxygenated species tend to have a higher solubility in water than terpenes (Graedel, 1979) and the ambient air was humid (relative humidity 50 to $100 \%$ ) throughout the measurement period with several millilitres of water trapped out of the sample line each day. It is possible therefore that these species may be lost to condensed water during sample collection or during the transfer of collected samples between wet and dry sample tubes. In addition, it is known that significant errors associated with the quantification of reactive and oxygenated compounds can arise (Larsen et al., 1997). The oxygenated species found here were not quantified due to uncertainty in their quantitative transfer.

The observed monoterpene concentrations were typically higher than those recorded by Serça et al. (2001) in Northern Congo (less than $20 \mathrm{pptV}$ ). Previously in tropical regions, $\alpha$ pinene has been found to be the dominant monoterpene in ambient air, reflecting the ubiquitous nature of its emission. The results here indicate ambient air concentrations of $\alpha$ pinene are similar to those recorded for $\beta$-pinene. Samples collected within the canopy, that comprised native species, contained similar levels of $\alpha$-pinene to the ambient air samples, but concentrations of $\beta$-pinene and limonene were generally lower in the canopy measurements. The expected lifetime of $\alpha$-pinene (approximately $3 \mathrm{~h}$ based on $24 \mathrm{~h}$ average $\mathrm{OH}$ and $\mathrm{O}_{3}$ concentrations of $5.5 \times 10^{5}$ molecules $\mathrm{cm}^{-3}$ and $7 \times 10^{11}$ molecules $\mathrm{cm}^{-3}$ respectively) is comparable with other commonly observed species such as $\beta$-pinene, and isoprene ( 4 to $5 \mathrm{~h}$ using the same parameters). This, combined with low wind speed during sampling, suggested that 
the ambient air composition was strongly influenced by the vegetation closest to the air inlet.

The highest concentrations in ambient air of any species quantified were recorded for limonene. Limonene has a short atmospheric lifetime of less than $2 \mathrm{~h}$ (assuming $24 \mathrm{~h}$ average $\mathrm{OH}$ and $\mathrm{O}_{3}$ concentrations of $5.5 \times 10^{5}$ molecules $\mathrm{cm}^{-3}$ and $7 \times 10^{11}$ molecules $\mathrm{cm}^{-3}$ respectively) and concentrations varied widely from tens of $\mathrm{pptV}$ to over $5000 \mathrm{ppt} \mathrm{V}$, with the largest variation observed during daylight hours and into the early evening. These observations can not be explained solely by the prevailing meteorological conditions (e.g. a strong emitter from a particular wind sector) at the time of sampling and may therefore also be influenced by more complex photochemical processes and competing reactions occurring in daylight hours, coupled with changes in the environmental factors that promoted limonene emissions. In contrast to these results, in the Amazon no single monoterpene species was found to be present at a higher concentration than isoprene at any time during the day, with total monoterpenes less than $1000 \mathrm{pptV}$ (Kesselmeier et al., 2000). The Amazon region is generally considered to have higher monoterpene emissions than West Africa but clearly there are some local influences at this Benin site that have not been previously predicted.

Emissions of terpene species arise due to a number of varying factors including temperature, sunlight exposure and sample specific factors such as age and location (Fehsenfeld et al., 1992). There was a weak correlation between measured limonene concentration and air temperature similar to that seen for isoprene. No further correlations with other measured meteorological factors were observed.

\subsection{Emissions sources}

Isoprene and monoterpenes are relatively reactive species with atmospheric lifetimes ranging from minutes to hours. Limonene has a shorter atmospheric lifetime than $\alpha$-pinene and this relatively short lifetime combined with the lack of degradation products found in the samples suggested a local source. In-canopy losses have been shown to occur for highly reactive species (Ciccioli et al., 1999) and therefore sources from open areas could dominate. Wind speeds were very low (less than $200 \mathrm{~cm} \mathrm{~s}^{-1}$ ) during the measurement period except for very brief periods of a few minutes duration immediately prior to rain storm events. In such calm conditions, the true wind direction is difficult to ascertain and the individual influence of plant species in different sectors could not be detected in the ambient air samples using meteorological data.

A comprehensive vegetation survey (Table 1) provided an assessment of the dominant species present around the sampling site. The species recorded included Burkea africana, Daniellia oliveri and Isoberlinia doka, members of the Caesalpiniaceae family, which are potential isoprene emitters (Klinger et al., 1998). Klinger et al also reported that a more limited number of plant families contained stored VOCs, a classification that included monoterpene compounds. The primary families identified were Annonaceae and Asteraceae which were not found at this site. However, Mangifera indica (mango) was found to contain stored monoterpenes and falls within the family Anacardiaceae (Klinger et al., 1998). Anacardium occidentale (cashew) is also a member of this family and was the dominant species in cultivated sectors around the site and especially close to the air inlet (Fig. 1). Anacardium occidentale is a crop species originating in South America but now grown widely in tropical regions of Africa and Asia.

Using branch and leaf enclosures, emissions from several of the dominant species found around the site were estimated (Table 2), including Isoberlinia doka, Burkea africana, Vitellaria paradoxa and Anacardium occidentale. It is clear from the results that the relatively high levels of monoterpenes observed at the site could be explained by the presence of the species Anacardium occidentale. In comparison, the native species showed much lower monoterpene emissions. Otter et al. (2002) reported higher isoprene emissions for Isoberlinia and Burkea in Southern Africa than measured here. This could be due to a combination of factors, including higher temperatures during sampling and other biological and environmental factors, however we do not have any evidence here to identify any single factor as responsible for the discrepancy. It is unlikely that the discrepancy could be accounted for by natural factors based current knowledge from previous studies (Klinger et al., 1998). The amount of isoprene emitted from Anacardium occidentale was also high, but for this compound there were also significant emissions from the native species sampled.

Anacardium occidentale is not native to Africa and is grown as a crop species in many tropical regions in Africa and Asia. The growing recognition of the importance of BVOCs as a factor in devising local air pollution abatement strategies has led to the examination of factors causing changes in emissions. Whilst changes in the physical climate and land use have been described (Stevenson et al., 2005; Lathiere et al., 2006), the effects on BVOC emissions of changes in the specific vegetation species present are less commonly considered. The effects of such changes on BVOC emissions in the USA were reported by Purves et al. (2004). In the southeastern USA in particular, increases in BVOC emissions which could result in significant changes in ozone production were one consequence of changes in the species compositions of forests and plantations. In tropical regions a few studies considering deforestation in the tropics have taken into account the effects of the species that replace native forest (Geron et al., 2006; Wiedinmyer et al., 2006). The effects in Africa are difficult to consider due to the lack of availability of detailed data, but these results suggest it will be an important factor to consider as the profiles of other regional pollutants change (Kelome et al., 2006; Unger et al., 2006). 
Table 2. Emissions estimates for isoprene and monoterpenes from vegetation species found around Djougou, Benin. For Isoberlinia doka the range shown represents the results from measurements from three different leaves or branches of the same plant. The other measurements are based on sampling from a single leaf or branch. Results are expressed in $\mathrm{ng}(\mathrm{g} \text { dry weight })^{-1} \mathrm{~h}^{-1}$.

\begin{tabular}{llllll}
\hline & isoprene & $\alpha$-pinene & $\beta$-pinene & p-cymene & limonene \\
\hline Isoberlinia doka & $135-1800$ & $11.8-216$ & $<$ lod-27.0 & $<$ lod-2.49 & $<$ lod-27.0 \\
Burkea africana & 475 & 4.98 & 0.663 & 0.981 & 1.66 \\
Vitellaria paradoxa & 97 & 280 & 43 & 21 & 22 \\
Anacardium occidentale & 3570 & 19900 & 8800 & 11700 & 20400 \\
\hline
\end{tabular}

Table 3. Terpene and sesquiterpene content of vegetation samples measured by direct thermal desorption. The monoterpenes and sesquiterpenes specifically named typically represent the 5 to 10 most abundant terpene compounds. Others include compounds that are not monoterpenes or sesquiterpenes, and those compounds that represent less than $0.1 \%$ of the peak area of the chromatogram. Amounts are expressed as a percentage of the total peak area of the chromatogram.

\begin{tabular}{llllll}
\hline & Monoterpenes & & Sesquiterpenes & & Others ${ }^{\mathrm{b}}$ \\
\hline Anacardium occidentale & $\alpha$-pinene & 5.10 & cedrene & 4.06 & 35.00 \\
& camphene & 0.43 & $\alpha$-himachalene & 1.31 & \\
& p-cymene & 13.18 & $\alpha$-humulene & 0.28 & \\
& limonene & 8.47 & copaene & 3.28 & \\
& $\alpha$-phellandrene & 11.98 & $\alpha$-neoclovene & 1.56 & \\
& terpinolene & 12.04 & $\alpha$-muurolene & 1.58 & \\
& & & $\alpha$-cadinene & 4.51 & \\
Burkea africana & none detected & - & none detected & - & 86.34 \\
Danielli oliveri & $\alpha$-pinene & 0.43 & $\alpha$-humulene & 14.78 & 69.40 \\
& & & $\alpha$-cadinene & 1.67 & \\
Isoberlinia doka & camphene & 0.79 & copaene & 1.67 & 87.22 \\
& $\beta$-pinene & 5.11 & $\alpha$-cadinene & 1.10 & \\
Parkia biglobosa & $\alpha$-pinene & 4.41 & calamenene & 1.34 & \\
& camphene & 0.57 & & - & 88.34 \\
Vitellaria paradoxa & camphene & 0.87 & copaene & 0.90 & 92.47 \\
& $\beta$-pinene & 4.90 & $\alpha$-cadinene & 0.86 & \\
Andropogon gayanus & $\alpha$-pinene & 0.48 & none detected & - & 87.26 \\
Dactylotenium aegyptium & $\beta$-pinene & 3.03 & none detected & - & 80.10 \\
\hline
\end{tabular}

${ }^{\mathrm{b}}$ Contains all other compounds found including monoterpenes and sesquiterpenes comprising a minor component of the sample.

\subsection{Direct thermal desorption - stored terpene composition}

Analysis of ambient air suggested that a wide variety of monoterpenes were produced by the vegetation sources found at the site. It is believed that temperature-only dependent terpene emissions arise from stored reservoirs of the compounds within the leaf structures (Kesselmeier and Staudt, 1999), unlike isoprene. Therefore the organic content of the biological matrix itself may mirror the monoterpene emssions from the vegetation species. No evidence of isoprene in the biological extractions was found, consistent with biosynthetic production and emission rather than storage. In contrast, analysis of leaf samples of the common woody and grassy species collected around the site highlighted several monoterpene and sesquiterpene compounds which were also present in the ambient and canopy samples (Table 3). The presence of the sesquiterpene $\alpha$-copaene, which has a similar lifetime to limonene, in the Anacardium occidentale biological sample highlighted the possible emission of this species and comprehensive GC analysis identified such compounds in ambient air. The relative amount of sesquiterpenes: $\alpha$ pinene was much higher in the biological samples compared to ambient air, potentially a result of a vapour pressure dependant partition from plant to atmosphere. For more reactive sesquiterpenes, losses during sampling may also become highly significant.

Although limonene was present in significant quantities in ambient air/enclosure samples, biological analysis indicated that there were many species with much shorter lifetimes 
(Calogirou et al., 1999) that would be difficult to detect in the ambient air samples due to the light winds and the distance between the inlet and the vegetation sources. The biological analysis indicated that very reactive terpenoid compounds including $\alpha$-phellandrene and $\alpha$-humulene were present stored within the woody species (particularly Anacardium occidentale and Daniellia oliveri) and were potentially available for emission. Table 3 highlights the most abundant monoterpenes and sesquiterpenes found in the analysed vegetation samples, present as $0.1 \%$ or more. For most tree species in Table 3, a substantial fraction of directly extractable organic material was not terpenoid in classification. This was common across all tree species and typically comprised light aldehydes (typically acetaldehyde, fufural, hexanal), long chain alkanes and fatty acids. Typically, between 30 and 50 volatile species in total were identified by GC in each sample. Di Carlo et al. (2004) showed that missing OH reactivity in rural forests increased with temperature and was consistent with underestimation of BVOC emission rates due to the presence of unknown BVOCs. Observations carried out by Holzinger et al. (2005) identified oxidation products present above a forest canopy that could be attributed to very reactive compounds. We used direct analysis of biological material as a route to probing the potential for very reactive emissions from vegetation. Since we studied the compounds "at source", short lifetime hydrocarbon terpenes were seen, however we did not observe their oxygenated degradation products in ambient air.

The biological sample analysis confirmed that Anacardium occidentale contained higher concentrations and a wider variety of identified monoterpene and sesquiterpene compounds compared to the native species. This agreed well with the leaf and branch emissions measurements in which fifteen unidentified compounds with terpenoid mass fragment characteristics were found in Anacardium occidentale compared to up to seven found in samples from Isoberlinia doka, Vitellaria paradoxa and Burkea africana.

\section{Conclusions}

Measurements of isoprene and terpene compounds were carried out in a rural area of Benin, West Africa. These measurements have provided an insight into the BVOCs present in a region previously poorly characterised. Isoprene was the dominant species present and concentrations were consistent with expectations based on data from other parts of Africa and models. Concentrations of monoterpenes were generally lower than isoprene but high concentrations of limonene, exceeding isoprene concentrations in ambient air at times, were observed. Canopy measurements and analysis of emissions at the leaf and branch level showed that this could be attributed largely to a single source, Anacardium occidentale. Sesquiterpenes were detected but not quantified in ambient air. The contribution of these compounds to secondary or- ganic aerosol formation is thought to be important and therefore further work to quantify these compounds is required.

We used direct thermal desorption to study volatile content of vegetation as a means to overcome problems of potential losses on emissions sampling. The presence of monoterpene and sesquiterpene compounds in biological material from two herbaceous and six woody species found at the site, including highly reactive compounds not seen in ambient air samples, was confirmed using this method. These compounds were generally limited to the woody plants but due to the possibility of biosynthetic production, more detailed in-situ emissions studies are required to allow an accurate assessment of all sources. The relative composition and strength of emissions was in agreement between cuvette/enclosure type measurements and those seen when the biological material was directly analysed.

The results presented here indicate that a non-native species Anacardium occidentale is a strong source of monoterpenes and possibly sesquiterpenes with emissions far greater than the surrounding native vegetation. Changes in the chemistry of the tropical region due to conversion to agricultural uses have largely been considered in the context of biomass burning. However, from the data shown here, there are clearly other effects of changing land use that should be considered when assessing impacts on regional atmospheric chemistry. The extent of replacement of indigenous species in tropical regions has been considerable in recent years. It is unknown what the extent of coverage for Anacardium occidentale was historically, is currently, or will be in the future, although there is evidence to suggest that over one third of land use in the Oueme basin incorporates Anacardium occidentale in varying proportions ${ }^{3}$. The implications for the effect on tropospheric chemistry of biogenic emissions from Africa are significant when the increase in anthropogenic pollutants from urban areas in the region is considered.

Acknowledgements. This work was supported by NERC (NE/B505570/1). The support of A. Mariscal of the Aérologie Laboratory and T. El-Fahem and A. Borgstedt of IRD for assistance with logistical matters in Benin is gratefully acknowledged. J. E. Saxton, A. C. Lewis and J. H. Kettlewell would also like to thank J. Hamilton and N. Watson for helpful discussions on adsorption tube analysis using GC-TOF/MS and GCxGC-TOF/MS. Based on a French Initiative, AMMA was built by an international scientific group and is currently funded by a large number of agencies, especially from France, UK, U.S. and Africa. It has been the beneficiary of a major financial contribution from the European Community's Sixth Framework Research programme. Detailed information on scientific coordination and funding is available on the AMMA international web site http://www.amma-international.org.

\footnotetext{
${ }^{3}$ GOCE-CT-2003-505401 RIVERTWIN A regional model for integrated water management in twinned river basins, D15: Soil information system for the Oueme basin, http://www.rivertwin.de/ Publications\&Reports.htm
} 
Edited by: A. Hofzumahaus

\section{References}

Andreae, M. O. and Crutzen, P. J.: Atmospheric aerosols: Biogeochemical sources and role in atmospheric chemistry, Science, 276(5315), 1052-1058, 1997.

Atkinson, R. and Arey, J.: Gas-phase tropospheric chemistry of biogenic volatile organic compounds: a review, Atmos. Environ., 37, S197-S219, 2003.

Cachier, H., Buatmenard, P., Fontugne, M., and Rancher, J.: Source Terms and Source Strengths of the Carbonaceous Aerosol in the Tropics, J. Atmos. Chem., 3(4), 469-489, 1985.

Calogirou, A., Larsen, B. R., and Kotzias, D.: Gas-phase terpene oxidation products: a review, Atmos. Environ., 33(9), 14231439, 1999.

Ciccioli, P., Brancaleoni, E., Frattoni, M., Di Palo, V., Valentini, R., Tirone, G., Seufert, G., Bertin, N., Hansen, U., Csiky, O., Lenz, R., and Sharma, M.: Emission of reactive terpene compounds from orange orchards and their removal by within-canopy processes, J. Geophys. Res.-Atmos., 104(D7), 8077-8094, 1999.

Delmas, R. A., Druilhet, A., Cros, B., Durand, P., Delon, C., Lacaux, J. P., Brustet, J. M., Serca, D., Affre, C., Guenther, A., Greenberg, J., Baugh, W., Harley, P., Klinger, L., Ginoux, P., Brasseur, G., Zimmerman, P. R., Gregoire, J. M., Janodet, E., Tournier, A., Perros, P., Marion, T., Gaudichet, A., Cachier, H., Ruellan, S., Masclet, P., Cautenet, S., Poulet, D., Biona, C. B., Nganga, D., Tathy, J. P., Minga, A., Loemba-Ndembi, J., and Ceccato, P.: Experiment for Regional Sources and Sinks of Oxidants (EXPRESSO): An overview, J. Geophys. Res.-Atmos., 104(D23), 30 609-30 624, 1999.

Di Carlo, P., Brune, W. H., Martinez, M., Harder, H., Lesher, R., Ren, X. R., Thornberry, T., Carroll, M. A., Young, V., Shepson, P. B., Riemer, D., Apel, E., and Campbell, C.: Missing OH reactivity in a forest: Evidence for unknown reactive biogenic VOCs, Science, 304(5671), 722-725, 2004.

Fehsenfeld, F., Calvert, J., Fall, R., Goldan, P., Guenther, A. B., Hewitt, C. N., Lamb, B., Liu, S., Trainer, M., Westberg, H., and Zimmerman, P.: Emissions of volatile organic compounds from vegetation and the implications for atmospheric chemistry, Global Biogeochem. Cy., 6(4), 389-430, 1992.

Fuentes, J. D., Lerdau, M., Atkinson, R., Baldocchi, D., Bottenheim, J. W., Ciccioli, P., Lamb, B., Geron, C., Gu, L., Guenther, A., Sharkey, T. D., and Stockwell, W.: Biogenic Hydrocarbons in the Atmospheric Boundary Layer: A Review, B. Am. Meteorol. Soc., 81(7), 1537-1575, 2000.

Geron, C., Owen, S., Guenther, A., Greenberg, J., Rasmussen, R., Bai, J. H., Li, Q.-J., and Baker, B.: Volatile organic compounds from vegetation in southern Yunnan Province, China: Emission rates and some potential regional implications, Atmos. Environ., 40, 1759-1773, 2006.

Graedel, T. E.: Terpenoids in the Atmosphere, Rev. Geophys., 17(5), 937-947, 1979.

Greenberg, J. P., Guenther, A. B., Madronich, S., Baugh, W., Ginoux, P., Druilhet, A., Delmas, R., and Delon, C.: Biogenic volatile organic compound emissions in central Africa during the Experiment for the Regional Sources and Sinks of Oxidants (EX-
PRESSO) biomass burning season, J. Geophys. Res.-Atmos., 104(D23), 30 659-30 671, 1999.

Guenther, A., Hewitt, C. N., Erickson, D., Fall, R., Geron, C., Graedel, T., Harley, P., Klinger, L., Lerdau, M., Mckay, W. A., Pierce, T., Scholes, B., Steinbrecher, R., Tallamraju, R., Taylor, J., and Zimmerman, P.: A Global-Model of Natural Volatile Organic-Compound Emissions, J. Geophys. Res.Atmos., 100(D5), 8873-8892, 1995.

Guenther, A., Karl, T., Harley, P., Wiedinmyer, C., Palmer, P. I., and Geron, C.: Estimates of global terrestrial isoprene emissions using MEGAN (Model of Emissions of Gases and Aerosols from Nature), Atmos. Chem. Phys., 6, 3181-3210, 2006, http://www.atmos-chem-phys.net/6/3181/2006/.

Guenther, A. B., Monson, R. K., and Fall, R.: Isoprene and Monoterpene Emission Rate Variability - Observations with Eucalyptus and Emission Rate Algorithm Development, J. Geophys. Res.-Atmos., 96(D6), 10 799-10 808, 1991.

Guenther, A. B., Zimmerman, P. R., Harley, P. C., Monson, R. K., and Fall, R.: Isoprene and Monoterpene Emission Rate Variability - Model Evaluations and Sensitivity Analyses, J. Geophys. Res.-Atmos., 98(D7), 12 609-12 617, 1993.

Holzinger, R., Lee, A., Paw, K. T., and Goldstein, A. H.: Observations of oxidation products above a forest imply biogenic emissions of very reactive compounds, Atmos. Chem. Phys., 5, 6775,2005 ,

http://www.atmos-chem-phys.net/5/67/2005/.

Kavouras, I. G., Mihalopoulos, N., and Stephanou, E. G.: Formation of atmospheric particles from organic acids produced by forests, Nature, 395(6703), 683-686, 1998.

Kavouras, I. G., Mihalopoulos, N., and Stephanou, E. G.: Formation and gas/particle partitioning of monoterpenes photo- oxidation products over forests, Geophys. Res. Lett., 26(1), 55-58, 1999.

Kelome, N. C., Leveque, J., Andreux, F., Milloux, M. J., and Oyede, L. M.: C-4 plant isotopic composition (delta C-13) evidence for urban $\mathrm{CO} 2$ pollution in the city of Cotonou, Benin (West Africa), Sci. Total Environ., 366(2-3), 439-447, 2006.

Kesselmeier, J., Kuhn, U., Wolf, A., Andreae, M. O., Ciccioli, P., Brancaleoni, E., Frattoni, M., Guenther, A., Greenberg, J., Vasconcellos, P. D., de Oliva, T., Tavares, T., and Artaxo, P.: Atmospheric volatile organic compounds (VOC) at a remote tropical forest site in central Amazonia, Atmos. Environ., 34(24), 40634072, 2000.

Kesselmeier, J. and Staudt, M.: Biogenic volatile organic compounds (VOC): An overview on emission, physiology and ecology, J. Atmos. Chem., 33(1), 23-88, 1999.

Klinger, L. F., Greenberg, J., Guenther, A., Tyndall, G., Zimmerman, P., M'Bangui, M., and Moutsambote, J. M.: Patterns in volatile organic compound emissions along a savanna-rainforest gradient in central Africa, J. Geophys. Res.-Atmos., 103(D1), 1443-1454, 1998.

Kuhn, U., Rottenberger, S., Biesenthal, T., Wolf, A., Schebeske, G., Ciccioli, P., Brancaleoni, E., Frattoni, M., Tavares, T. M., and Kesselmeier, J.: Isoprene and monoterpene emissions of Amazonian tree species during the wet season: Direct and indirect investigations on controlling environmental functions, J. Geophys. Res.-Atmos., 107(D20), 8071, doi:10.1029/2001JD000978, 2002.

Lacaux, J. P., Delmas, R. A., Cros, B., Lefeivre, B., and An- 
dreae, M. O.: Influence of biomass burning emissions on precipitation chemistry in the equatorial forest of Africa, in Global biomass burning: atmospheric, climatic, and biospheric implications, Levine, J. S., MIT Press, USA, 167-173, 1991.

Larsen, B., Bomboi-Mingarro, T., Brancaleoni, E., Calogirou, A., Cecinato, A., Coeur, C., Chatzianestis, I., Duane, M., Frattoni, M., Fugit, J. L., Hansen, U., Jacob, V., Mimikos, N., Hoffmann, T., Owen, S., Perez-Pastor, R., Reichmann, A., Seufert, G., Staudt, M., and Steinbrecher, R.: Sampling and analysis of terpenes in air, An interlaboratory comparison, Atmos. Environ., 31, 35-49, 1997.

Lathiere, J., Hauglustaine, D. A., Friend, A. D., Noblet-Ducoudre, N., Viovy, N., and Folberth, G. A.: Impact of climate variability and land use changes on global biogenic volatile organic compound emissions, Atmos. Chem. Phys., 6, 2129-2146, 2006, http://www.atmos-chem-phys.net/6/2129/2006/.

Lindesay, J. A., Andreae, M. O., Goldammer, J. G., Harris, G., Annegarn, H. J., Garstang, M., Scholes, R. J., and vanWilgen, B. W.: International Geosphere-Biosphere Programme International Global Atmospheric Chemistry SAFARI-92 field experiment: Background and overview, J. Geophys. Res.-Atmos., 101(D19), 23 521-23 530, 1996.

Muller, J. F.: Geographical-Distribution and Seasonal-Variation of Surface Emissions and Deposition Velocities of Atmospheric Trace Gases, J. Geophys. Res.-Atmos., 97(D4), 3787-3804, 1992.

Otter, L. B., Guenther, A., and Greenberg, J.: Seasonal and spatial variations in biogenic hydrocarbon emissions from Southern African savannas and woodlands, Atmos. Environ., 36, 42654275, 2002.

Ozel, M. Z., Gogus, F., and Lewis, A. C.: Determination of Teucrium chamaedrys volatiles by using direct thermal desorptioncomprehensive two-dimensional gas chromatography-time-offlight mass spectrometry, J. Chromatography A, 1114(1), 164169, 2006.

Penuelas, J., Llusia, J., Asensio, D., and Munne-Bosch, S.: Linking isoprene with plant thermotolerance, antioxidants and monoterpene emissions, Plant Cell Environ., 28(3), 278-286, 2005.

Piccot, S. D., Watson, J. J., and Jones, J. W.: A Global Inventory of Volatile Organic-Compound Emissions from Anthropogenic Sources, J. Geophys. Res.-Atmos., 97(D9), 9897-9912, 1992.

Purves, D. W., Caspersen, J. P., Moorcroft, P. R., Hurtt, G. C., and Pacala, S. W.: Human-induced changes in US biogenic volatile organic compound emissions: evidence from long-term forest inventory data, Global Change Biol., 10(10), 1737-1755, 2004.
Serca, D., Guenther, A., Klinger, L., Vierling, L., Harley, P., Druilhet, A., Greenberg, J., Baker, B., Baugh, W., Bouka-Biona, C., and Loemba-Ndembi, J.: EXPRESSO flux measurements at upland and lowland Congo tropical forest site, Tellus B, 53(3), 220 234, 2001.

Sharkey, T. D. and Yeh, S. S.: Isoprene emission from plants, Annu. Rev. Plant Phys., 52, 407-436, 2001.

Stevenson, D., Doherty, R., Sanderson, M., Johnson, C., Collins, B., and Derwent, D.: Impacts of climate change and variability on tropospheric ozone and its precursors, Faraday Discuss., 130, 41-57, 2005.

Swap, R. J., Annegarn, H. J., and Otter, L.: Southern African Regional Science Initiative (SAFARI 2000): summary of science plan, South African J. Sci., 98(3-4), 119-124, 2002.

Swap, R. J., Annegarn, H. J., Suttles, J. T., King, M. D., Platnick, S., Privette, J. L., and Scholes, R. J.: Africa burning: A thematic analysis of the Southern African Regional Science Initiative (SAFARI 2000), J. Geophys. Res.-Atmos., 108(D13), 8465 , doi:1029/2003JD003747, 2003.

Trainer, M., Williams, E. J., Parrish, D. D., Buhr, M. P., Allwine, E. J., Westberg, H. H., Fehsenfeld, F. C., and Liu, S. C.: Models and Observations of the Impact of Natural Hydrocarbons on Rural Ozone, Nature, 329(6141), 705-707, 1987.

Unger, N., Shindell, D. T., Koch, D. M., Amann, M., Cofala, J., and Streets, D. G.: Influences of man-made emissions and climate changes on tropospheric ozone, methane, and sulfate at 2030 from a broad range of possible futures, J. Geophys. Res.-Atmos., 111, D12313, doi:10.1029/2005JD006518, 2006.

Wiedinmyer, C., Tie, X., Guenther, A., Neilson, R., and Granier, C.: Future changes in biogenic isoprene emissions: How might they affect regional and global atmospheric chemistry?, Earth Interactions, 10(3), 1-19, 2006.

Williams, J., Roberts, J. M., Fehsenfeld, F. C., Bertman, S. B., Buhr, M. P., Goldan, P. D., Hubler, G., Kuster, W. C., Ryerson, T. B., Trainer, M., and Young, V.: Regional ozone from biogenic hydrocarbons deduced from airborne measurements of PAN, PPN, and MPAN, Geophys. Res. Lett., 24(9), 1099-1102, 1997.

Yu, J. Z., Griffin, R. J., Cocker, D. R., Flagan, R. C., Seinfeld, J. H., and Blanchard, P.: Observation of gaseous and particulate products of monoterpene oxidation in forest atmospheres, Geophys. Res. Lett., 26(8), 1145-1148, 1999. 